\author{
V.Yu. DANILCHENKO, V.F. MAZANKO, \\ O.V. FILATOV, and V.E. IAKOVLEV \\ G. V. Kurdyumov Institute for Metal Physics, NAS of Ukraine, \\ 36 Academician Vernadsky Blvd., \\ UA-03142 Kyiv, Ukraine
}

\title{
EFFECT OF CYCLIC MARTENSITIC $\gamma-\varepsilon$ TRANSFORMATIONS ON DIFFUSION CHARACTERISTICS OF COBALT IN AN IRON-MANGANESE ALLOY
}

This review article analyses the results of experimental investigations of the influence of the cyclic direct $\gamma-\varepsilon$ (f.c.c. - h.c.p.) and reverse $\varepsilon-\gamma$ (h.c.p. - f.c.c.) martensitic transformations (MT) on the diffusion characteristics of Co atoms in $\Gamma 18 \mathrm{C} 2(\mathrm{Fe}-$ 18.3 wt. $\% \mathrm{Mn}-2.1$ wt. $\% \mathrm{Si}$ ) alloy with low stacking-fault energy. With using of the radioactive isotopes via autoradiography and the layer analysis methods, it is shown the significant intensification of mobility of Co atoms by $\gamma \leftrightarrow \varepsilon$ transformations is determined by two different independent mechanisms: due to the MT (athermal mechanism) and by means of the mechanism of thermal activation in the area of structural defects formed during the $\gamma-\varepsilon$ and $\varepsilon-\gamma$ transformations. The possibility of Co atom transport by means of the athermal mechanism in the process of cyclic martensitic transformations (CMT) by moving of interstitial atoms and their complexes along the close-packed (111) $)_{\gamma}$ and $(001)_{\varepsilon}$ planes in the crystal lattices of f.c.c. austenite and h.c.p. martensite, respectively (crowdion mechanism) is analysed. The ability of the crowdion complexes to move with a velocity exceeding the velocity of sound in a crystal in the field of high internal stresses arising during high-rate deformation of austenite in a MT process is taken into account. The regularities of accumulation of such structural defects in the CMT process as disorientation of the crystal lattice and chaotic stacking faults (CSF) are investigated by the x-ray methods for the single-crystalline and polycrystalline samples. The intensification of diffusion processes in a phase-hardened alloy by the thermal-activation mechanism is attributed to the increase in the Co-atoms' mobility in the region of accumulation of defects in the crystal structure. An analysis of the regularities of accumulation of different types of defects with an increase in the phase-hardening degree made it possible to establish a certain sequence of their influence on the diffusion mobility 
of Co atoms. The results of the investigation develop the physical notions about the diffusion of substitutional atoms in alloys with a developed system of the structural defects of different types (dislocations, small-angle sub-boundaries of fragments, large-angle grain boundaries, deformation twinning boundaries, CSF). The obtained new experimental data can be used to develop a model of diffusion in the region of the linear and planar structural defects at low temperatures (below the half of the melting point). The perspective of practical application of the diffusionintensification regularities for optimization of chemical-and-thermal treatment regimes and dispersion hardening processes for metastable alloys is determined. A significant acceleration (by means of the CMT) of the diffusion of substitutional atoms at low temperatures opens up new additional possibilities of the dispersion solidification technology.

Keywords: martensitic transformation, diffusion, stacking faults, dislocation, phase hardening, sub-boundaries of fragments.

\section{Introduction}

The phenomenon of the diffusion in metals and alloys has a wide application in the industrial thermal and chemical-and-thermal treatment processes. As much as the diffusion is a direct after-effect of thermal atom fluctuations, the main treatment processes are carried out at high temperatures $\left(0.6 T_{\text {melt }}-0.9 T_{\text {melt }}\right.$, where $T_{\text {melt }}$ is a melting temperature) with long isothermal exposures. In some cases, the effect of alloy saturation by diffusion unable to implement because of low diffusion mobility of one of the diffusants. The rise of diffusion mobility of the atoms up to the necessary level for realization of the optimal treatment regimes is reasonable only in limited number of cases by means of rising of the temperature or time of isothermal exposure.

Practical realization of a possibility of atom diffusion mobility increasing at technologically convenient low temperatures can become the new development stage of material treatment methods with using of diffusion processes. Considering this, the problem of significant (on orders of magnitude) increasing of the diffusion coefficient in metal systems has a pronounced fundamental character [1-6]. One can solve this problem by usage of the significant dependence of diffusion characteristics on the dimensions and concentration of the structure and substructure elements and on the main crystal-structure defect types. Significant acceleration of diffusion processes can be induced by high-energy treatment, at which the gradient structure-and-phase state in steels and alloys forms [7-14]. The new complex of physical-and-mechanical characteristics, including diffusion characteristics, can be formed under the structure fragmentation to the ultrafine and/or nanoscale level. Such a fragmentation level is reachable via the CMT.

As result of CMT in metastable alloys, the line and planar defects of the crystal structure are generated (dislocations, additional nanograin 
boundaries, stacking faults, sub-boundaries of disoriented fragments and deformational twins) [15-18]. In the region of such defects, the diffusion mobility of substitution atoms and introduction atoms under low temperatures (lower than $0.5 T_{\text {melt }}$ ) can rise on orders. Thereby, in the metastable Fe-based alloys, the idea of a rising of intensification of the low-temperature diffusion mobility with a goal of regulation of diffusion processes that forms useful properties can be realized via the internal factor MT without using of external high-energy impacts. The possibility of diffusion acceleration of the substitutional atoms via the $\gamma-\alpha-\gamma$ (f.c.c. - b.c.c. - f.c.c.) CMT was shown experimentally in Ref. [19]. Effect of the (f.c.c.-h.c.p.-f.c.c.) CMT on the diffusion processes in alloys with low energy of stacking faults (SF) remains practically not studied.

Addition intensification of the diffusion processes is possible under condition of accumulation of the crystal structure defects as result of CMT of different types [19-22]. Such systematic investigations are not performed up to present time, and, therefore, the significant resource of intensification of the diffusion processes which can be used for development of intensive methods of thermal and chemical-and-thermal treatment remains unrealized.

Phase transformations of different types can effectively influence on diffusive mobility of substitution atoms and introduction atoms in metastable alloys [23-26]. Degree and quality of such an influence depend on alloys structural state, which forms because of the phase transformations. Phase and structural transformations in metals and alloys, accompanied with volume effect and therefore formed certain system of crystal structure defects, cause the intensification of diffusion processes and stimulate mass transfer on macroscopic distance. Martensitic $\gamma-\alpha-\gamma$ transformations in the $\mathrm{Fe}-\mathrm{Ni}$ alloys substantially accelerate the diffusion of atoms in the reverted austenitic phase. Diffusive mobility of the atoms of alloying elements substantially depends on cooling and heating conditions, which necessary for realization of the direct $\gamma-\alpha$ and reverse $\alpha-\gamma$ MT, respectively.

In the $\mathrm{Fe}-\mathrm{Mn}$ alloys, the $\gamma-\varepsilon-\gamma$ transformations occur and result in an increasing the density of dislocations in the reverted austenitic phase by the order of magnitude [27] (for comparison, the density of dislocations after $\gamma-\alpha-\gamma$ transformation increase by three orders of magnitude $[15,16])$. Difference in increase of the density of dislocation caused by the different magnitude of the volume effect of $\gamma-\alpha$ and $\gamma-\varepsilon$ transformations $(3-4 \%$ and $1.75 \%$, respectively). In reverted iron-manganese austenite with low energy of stacking faults, the multiple $\gamma-\varepsilon-\gamma$ transformations have caused the accumulation of the CSF, but have not lead to significant structure fragmentation and to form of the additional sub-boundaries. 
A significant difference of structure state and degree of the imperfection of crystal lattice of the phase components formed due to the $\gamma-\alpha-\gamma$ and $\gamma-\varepsilon-\gamma$ transformations points out on necessity of additional study of effect of the $\gamma-\varepsilon-\gamma$ transformations on regularities of diffusion in alloys with low SF energy. Only one work is currently known [28], where authors experimentally studied the effect of cyclic $\gamma \leftrightarrow \varepsilon$ transformations in cobalt and $\mathrm{Fe}-\mathrm{Mn}$ alloys on the parameters of the diffusion of substitutional atoms. Significant increase of the diffusion mobility of substitutional atoms was revealed. However, in Ref. [28], authors obtained the integral result of intensification of the diffusion processes due to the general action of MT factors. In Ref. [29], authors revealed the regularities of diffusion intensification of carbon atoms in metastable $\mathrm{Fe}-18.3$ wt. $\% \mathrm{Mn}-2.1$ wt.\% Si alloy because of creation of the system of crystal structure defects via the $\gamma \leftrightarrow \varepsilon$ MT. In this article, at the first time, an attempt is made to separate the contribution to the intensification of the mobility of substitution atoms in the $\mathrm{Fe}-\mathrm{Mn}$ alloy of the martensite $\gamma-\varepsilon-\gamma$ transformations and of the defects of the crystal structure formed by direct $\gamma-\varepsilon$ and reverse $\varepsilon-\gamma$ MT.

\section{Materials and Experimental Technique}

The studies were performed for a metastable $\mathrm{Fe}-\mathrm{Mn} \Gamma 18 \mathrm{C} 2(\mathrm{Fe}-$ 18.3 wt. $\% \mathrm{Mn}-2.1$ wt.\% Si) alloy, where a high completeness of $\gamma-\varepsilon$ transformation (up to $90 \%$ of martensitic $\varepsilon$-phase) takes place. Cyclic direct $\gamma-\varepsilon$ and reverse $\varepsilon-\gamma$ transformations were sequentially realized in alloy during cooling in the liquid nitrogen and subsequent heating in the salt bath at a temperature of $380^{\circ} \mathrm{C}$. In this case, it was reached the maximal cooling rate within the range of direct transformations $\left(20^{\circ} \mathrm{C} / \mathrm{s}\right)$ and the heating rate within the range of reverse transformations $\left(80^{\circ} \mathrm{C} / \mathrm{s}\right)$. Such a thermal cycling regime resulted to deceleration of relaxation processes and provided an effective accumulation of structural defects due to both direct and reverse transformations. These structural defects can significantly effect on diffusion processes in the phasehardened alloys. Indeed, authors [30] noted a considerable increasing of diffusion coefficient of $\mathrm{Fe}$ and $\mathrm{Tl}$ only when a certain critical thermal cycling rate was reached. After the $\gamma-\varepsilon-\gamma$ transformations, a diffusion annealing of the phase-hardened alloys was performed at $250^{\circ} \mathrm{C}$ and $325{ }^{\circ} \mathrm{C}$.

X-ray investigations of the polycrystalline samples were performed using the automated diffractometer DRON-3 in the radiation of iron anode monochromatized with a lithium fluoride. Single-crystalline samples were investigated in a RKV-86M1 rotation chamber in the radiation of iron anode with fixation of the diffraction pattern by photo method. 
The amount of $\varepsilon$-martensite can be calculated by the ratio of integral intensity of (111) $)_{\gamma}$ and $(002)_{\varepsilon}$ diffraction reflexes [27]:

$$
M_{\varepsilon}=100 \%\left[1+0.27\left(I_{(11)_{\gamma} /} / I_{(002) \varepsilon}\right)\right]^{-1} .
$$

Using these reflexes from the austenite and $\varepsilon$-martensite crystallographic planes, which were parallel in accordance with orientation relations between the f.c.c. and h.c.p. lattices, we can calculate an amount of $\varepsilon$-phase without decrease in accuracy of the measurement in case of the appearance of texture in a process of the cyclic heating and cooling.

In order to characterize the degree of imperfection of the crystal lattice of phase-hardened alloy, it was measured the maximal angular disorientation $\psi$ of austenitic and $\varepsilon$-martensitic lattices (on single-crystalline samples) and the CSF concentration (on polycrystalline samples). The $\psi$ value, which characterizes the possibility of formation of lowangle dislocation sub-boundaries of fragments, was measured by the value of azimuth smearing of (200) $)_{\gamma}$ and $(101)_{\varepsilon}$ reflexes at the diffraction pattern from single-crystalline samples [15]. To define $\psi$ angle, the length of diffraction spot $a$ on the azimuth and the distances between the ends of spot and equator $h_{1}$ and $h_{2}$ were found [22].

The $\psi$ value was calculated using the formula

$$
\sin (\psi / 2)=\sqrt{a^{2}-(b-c)^{2} /(4 b c)},
$$

where $b=\sqrt{h_{1}^{2}+r^{2}}, c=\sqrt{h_{2}^{2}+r^{2}}, r$ is radius of the x-ray chamber.

The concentration $\alpha$ of the CSF in f.c.c. crystal lattice was measured by the value of change of the Bragg angles of certain diffraction reflexes. According to Refs. [31, 32] for f.c.c. structure, which contains the $\mathrm{SF}$ in planes $\{111\}$, the Bragg angle remains unchanged in those reflexes, where the Miller indices satisfy such requirements (in cubic coordinates): $h+k+l=3 N, 2 h-k-l=6 N^{\prime}$, where $N$ and $N^{\prime}$ are integers.

For the austenite $\Gamma 18 \mathrm{C} 2$ alloy, the $\alpha$ value was defined by the mutual shift of Bragg angles of the (200) $)_{\gamma}$ and (111) $)_{\gamma}$ reflexes:

$$
\Delta\left(2 \theta_{200}-2 \theta_{111}\right)=-45 \alpha_{\Sigma} \sqrt{3}\left(2 \operatorname{tg} \theta_{200}-\operatorname{tg} \theta_{111}\right) /\left(2 \pi^{2}\right),
$$

where $\theta$ is the Bragg angle and $\alpha_{\Sigma}$ is the CSF concentration.

In h.c.p. lattice, the $\alpha_{\Sigma}$ value can be defined from physical broadening of such reflexes satisfying the conditions of $h-k=3 N \pm 1$ and $l \neq 0$ [33-36]. Note that CSF does not cause the broadening of ( $h k 0)$ reflexes.

Concentration of CSF in $\{001\}_{\varepsilon}$ crystallographic planes can be calculated using the formula [21]

$$
B=\sqrt{1-\left[\left(1-3 \alpha_{\Sigma}\left(1-\alpha_{\Sigma}\right)\right]\right.} / \sqrt{1+\left[\left(1-3 \alpha_{\Sigma}\left(1-\alpha_{\Sigma}\right)\right]\right.},
$$

where $B$ is a half-width of $(h k l)$ reflex. The $\alpha_{\Sigma}$ value in this expression denotes a CSF concentration without their separation into deformed and twinned ones. 
Investigations of the diffusion mobility of Co atoms can be performed by the radioactive isotopes method. The layer of ${ }^{60} \mathrm{Co}$ radioactive isotopes of $0.5 \mu \mathrm{m}$ thickness was electrolitically coated on the polished surface of flat-parallel samples of the alloy with dimension of $10 \times 10 \times 5 \mathrm{~mm}^{3}$. The distribution of Co atoms in the depth was determined by the autoradiography and layer removing methods with a measurement of the $\beta$-activity of ${ }^{60} \mathrm{Co}$ radioisotope (Gruzin method [37]). After removing of each layer, an integral activity was measured on 'Beta' analyser, and by these data, the concentration curve of the distribution of radioactive isotope by depth of sample was plotted. The thickness of the removed layer was determined by weighing on microanalytical weigh-scales, using the formula

$$
\Delta h=\left(h_{0} / P_{0}\right) \Delta P
$$

here, $h_{0}$ and $P_{0}$ are the sample' thickness and weight, respectively; $\Delta h$ and $\Delta P$ are the thickness and weight of removed layer, respectively.

Diffusion coefficient of Co, $D$, can be calculated via the formula

$$
D=-(4 \tau \operatorname{tg} \alpha)^{-1},
$$

where $\tau$ is the duration of a diffusion annealing, $\alpha$ is the slope angle of a straight line to the abscissa axis at the graphs of $\ln I\left(x^{2}\right)$ ( $I$ is specific $\beta$-activity of a residue of sample after layer removing of $x$ thickness). The error in determining the diffusion coefficient does not exceed $20 \%$.

\section{Regularities of the Accumulation of Defects in Austenitic and Martensitic Phases Due to the Cyclic $\gamma-\varepsilon$ MT}

Previously, it was shown that due to a cycle of $\gamma \leftrightarrow \varepsilon$ transformations in $\mathrm{Fe}-\mathrm{Mn}$ alloys, the density of dislocations in reverted austenite increases by the order of magnitude, and a further increase of the number of $\gamma \leftrightarrow \varepsilon$ transformations up to hundreds of cycles does not cause a significant increase in the density of dislocations [35]. In $\mathrm{Fe}-\mathrm{Mn}$ alloys, the formation of such structural defects as the large-angle boundaries of austenitic grains is not observed similarly to the $\mathrm{Fe}-\mathrm{Ni}$ alloys [38]. However, after the multiple $\gamma \leftrightarrow \varepsilon$ transformations, the small-angle subboundaries of fragments that can be characterized by the $\psi$ angle of the maximum disorientation of crystalline lattice were formed.

$\mathrm{X}$-ray studies of single-crystalline samples showed that, in the phase-hardened $\Gamma 18 \mathrm{C} 2$ alloy, the $\psi$ angle monotonously increases with the increasing the number of $\gamma-\varepsilon-\gamma$ cycles and after $100 \gamma-\varepsilon-\gamma$ cycles it reached values of $9^{\circ}$ and $6.5^{\circ}$ for $\gamma$-phase (Fig. 1, curve 1) and $\varepsilon$-phase (Fig. 2, curve 1), respectively. As a result of the multiple cycles, the value of the $\psi$ angle was significantly less than the value reached because of $\gamma-\alpha-\gamma$ cycles in the iron-nickel alloys [38]. This is due to the higher structural reversibility of direct $\gamma-\varepsilon$ and reverse $\varepsilon-\gamma$ transitions. 

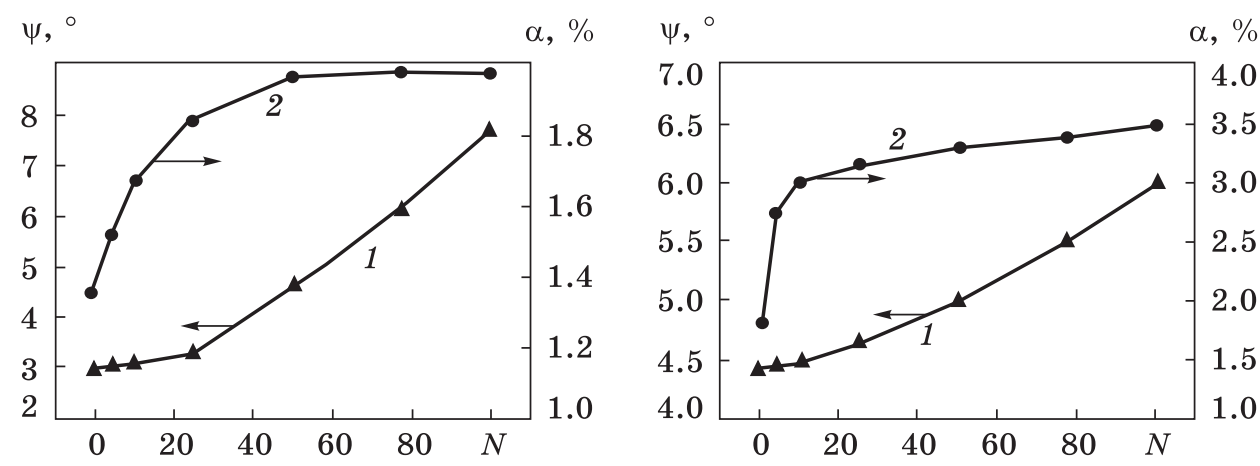

Fig. 1. Maximal disorientation angle $\psi$ (1) and CSF concentration $\alpha$ (2) vs. the number of $\gamma \leftrightarrow \varepsilon$ cycles $(N)$ in the crystalline lattice of austenite

Fig. 2. The same as in the previous figure, but for $\varepsilon$-martensite

It should be noted that the $\psi$ angle, even at intensive $\gamma \leftrightarrow \varepsilon$ cycling (the hundreds of cycles) do not exceed the value of $10^{\circ}$ for austenite, at that the disorientation angle of $14-15^{\circ}$ attributes to the large-angle boundaries of the grains. This means that cyclic $\gamma \leftrightarrow \varepsilon$ transformations can form only the small-angle sub-boundaries of the austenite fragmentso and it is impossible to form new grains of reverted austenite due to the accumulation of the lattice disorientation, which would differ from the orientation of the initial grain, as it was the case for iron-nickel alloys after multiple $\gamma-\alpha-\gamma$ transformations.

After the cyclic $\gamma \leftrightarrow \varepsilon$ transformations in the reverted austenite and $\varepsilon$-martensite of the $\mathrm{Fe}-\mathrm{Mn}$ alloys with low SF energy, the CSF was formed on the crystallographic planes $\{111\}_{\gamma}$ and $\{001\}_{\varepsilon}$. The CSF in the f.c.c. and h.c.p. structures showed the ability to the accumulation. In this connection, the regularities of formation and accumulation of CSF were studied in austenite and $\varepsilon$-martensite of the $\Gamma 18 \mathrm{C} 2$ alloy, which was phase-hardened by $\gamma \leftrightarrow \varepsilon$ transformations.

After the first $\gamma-\varepsilon-\gamma$ cycle, the concentration of the CSF in austenite was approximately 0.013 . After 50 such cycles, it reached the value of 0.02 , and after further increase in the number of cycles, it increased insignificantly (Fig. 1, curve 2). The concentration of the CSF in $\varepsilon$-martensite after the first cycle reached a greater value of 0.018 and increased to 0.035 with increasing number of cycles (Fig. 2, curve 2). Accumulation of the CSF was observed at the condition the quenched alloy was heated in the interval of reverse $\varepsilon^{-} \gamma$ transformation at a rate higher than the critical $\left(60^{\circ} \mathrm{C} / \mathrm{s}\right)$.

The formation and accumulation of CSF in reverted austenite after multiple direct $\gamma-\varepsilon$ and reverse $\varepsilon-\gamma$ transformations can be related both as to the thermal stresses, which arose during cyclic coolings and heatings, and with an increase of the degree of phase hardening, which was 
Fig. 3. The change of CSF concentration in the austenite (1) and $\varepsilon$-martensite (2) alloys phase-hardened by 100 cycles of $\gamma \leftrightarrow \varepsilon$ transformations depending on temperature of isothermal annealing for $30 \mathrm{~min}$

determined by an increase in the number of $\gamma \leftrightarrow \varepsilon$ transformations. It has been shown the appearance of the CPD in the austenite of $\mathrm{Fe}-\mathrm{Mn}$ alloys with low energy of the SF was determined mainly by the formation

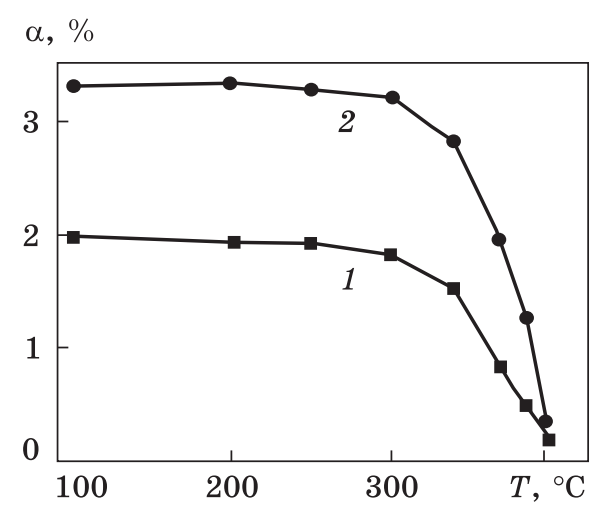
of the martensitic $\varepsilon$-phase and, at least, by thermal stresses [38]. This was evidenced by the experimental fact of an increase of the CSF concentration in the condition of the increase of $\varepsilon$-martensite amount. Such a regularity previously observed for both carbon-free and carbon Fe-Mn alloys [36, 39].

Thus, as a result of cyclic $\gamma \leftrightarrow \varepsilon$ martensitic transformations in the $\Gamma 18 \mathrm{C} 2$ alloy, there are appeared and accumulated dislocations, smallangle sub-boundaries characterized by the disorientation of the crystalline lattice of austenite and $\varepsilon$-martensite, and the CSF in both phases.

In connection with the possible influence of these defects of the crystalline structure on the intensity of diffusion processes in a phasehardened alloy $\Gamma 18 \mathrm{C} 2$, the investigation of the thermal stability of these defects was carried out.

As revealed, the annealing of the alloy, phase-hardened by $100 \gamma \leftrightarrow \varepsilon$ transformations, did not lead to a significant change in the density of dislocations and the maximum angle of disorientation of the crystalline lattice of $\gamma$ - and $\varepsilon$-phases within the interval of $100-400{ }^{\circ} \mathrm{C}$. However, under certain annealing regimes, the CSF in austenitic and martensitic phases exhibited thermal instability. The isothermal annealings at the temperatures of $50-300{ }^{\circ} \mathrm{C}$ did not lead to changes in the concentration of CSF, when the amount of $\varepsilon$-martensite did not change. Heating to the temperatures above $300{ }^{\circ} \mathrm{C}$ led to a significant decrease in the density of CSF. At the same time, a complete correlation was observed between changes in the density of the CSF in austenite and martensite (Fig. 3, curves 1 and 2). The interval of the decrease of CSF concentration coincided with the interval of the reverse $\varepsilon^{-\gamma}$ transformation. After completing the reverse transformation, the CDP completely disappeared. It should be noted that in Ref. [36], the CSF in the austenitic phase were more thermally stable than the martensitic phase; they were annealed at a temperature higher than the temperature of the end of reverse $\varepsilon^{-} \gamma$ transformation. 


\section{Characteristics of the Diffusion Processes in the Phase-Hardened Alloy}

Analysis of the depth distribution of Co atoms showed that due to the cyclic $\gamma \leftrightarrow \varepsilon$ transformations without additional diffusion annealing, their penetration into the volume of the alloy was at a certain depth. Already after the first cycle of transformations, the depth of penetration of Co atoms was $3.5 \mu \mathrm{m}$ (measurement accuracy is of $0.5 \mu \mathrm{m}$ ) (Fig. 4, curve 1). An increase in the number of cycles resulted in the further penetration of Co atoms. After 50 and 200 cycles, the penetration depth was 7 and $13 \mu \mathrm{m}$ respectively (Fig. 4, curves 2 and 3 ).

The next diffusion annealing of a phase-hardened alloy led to penetration of the cobalt atoms for a greater distance. For example, after the first and hundredth cycles, as a result of the subsequent annealing for a 2500 hours at a temperature of $250{ }^{\circ} \mathrm{C}$, the depth increased to 80 and $133 \mu \mathrm{m}$ (Fig. 5, $a$, curves 1, 2). An increase of the annealing temperature up to $325^{\circ} \mathrm{C}$ caused an additional penetration of the cobalt atoms into the depth of alloy (Fig. 5, $b$ ).

Thus, the significant intensification of Co caused by the cyclic $\gamma \leftrightarrow \varepsilon$ transformations relates to the action of two independent mechanisms: the athermal and the mechanism of thermal activation. The first mechanism was determined by the motions of atoms in the field of internal stresses that aroused in a result of direct $\gamma-\varepsilon$ transformation and accumulated at the repeated cyclic $\gamma \leftrightarrow \varepsilon$ transformations. The dependency of the penetration depth of Co isotope, at the conditions of the accumulation of internal stresses, has shown by curve 1 in Fig. 6 . At a subsequent diffusion annealing, the penetration occurred on macroscopic distances (Fig. 6, curves 2,3). Indeed, if the depth of penetration by the athermal mechanism was $12-13 \mu \mathrm{m}$, then by a combined mechanism (an athermal mechanism and a next one of thermal activation), the macroscopic distance was $145-170 \mu \mathrm{m}$.

The calculation of the diffusion coefficient of cobalt by its concentric distribution of the isotope in the alloy after the transformation cycles without additional annealing (Fig. 4, curves 1-3) could not be carried out. The latter is because of the im-

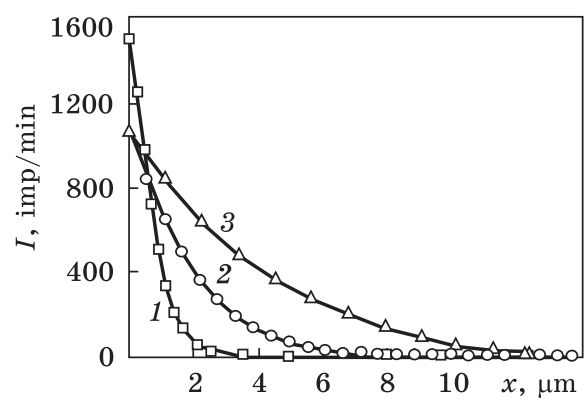
possibility of correct determination of the duration of cobalt penetration in the volume of alloy, which is obviously comparable to the occurrence time of MT. The mechanism

Fig. 4. Concentration distribution of Co isotope atoms after one (1), 50 (2), and 200 (3) cycles 

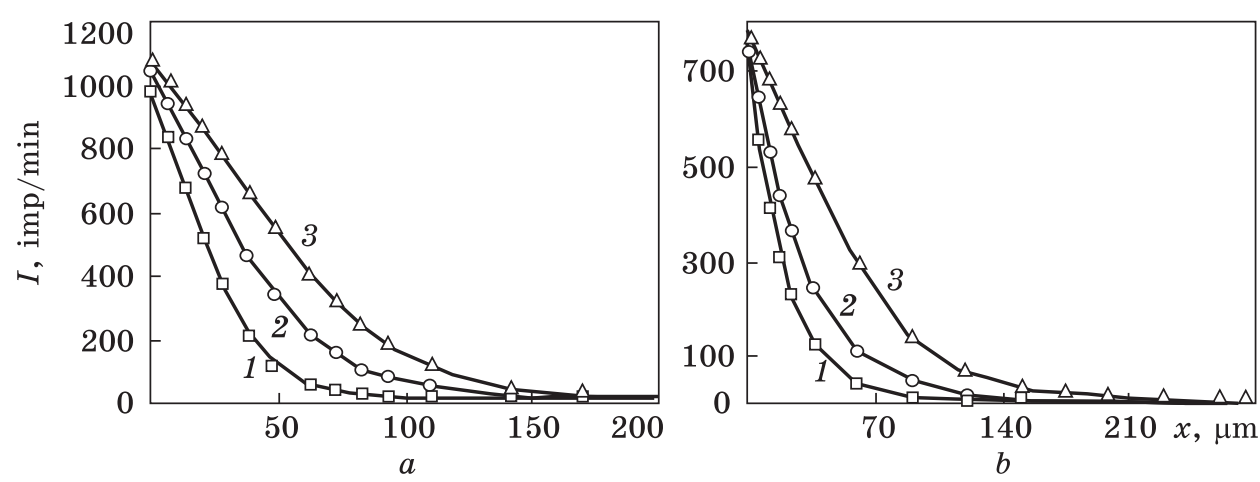

Fig. 5. Concentration distribution of Co isotope atoms after one (1), 100 (2), and 200 (3) cycles, and subsequent diffusion annealing at the temperatures of $250{ }^{\circ} \mathrm{C}(a)$ and $325^{\circ} \mathrm{C}(b)$

of the cobalt atoms transfer should be considered to be related to the structural f.c.c.-h.c.p.-f.c.c. reconstruction and the associated resultant distribution of force field of the stresses and of the moving dislocations due to the change in the volume and shape of the crystals undergoing transformation. Increasing the depth of penetration in the conditions of the repetition of transformation cycles showed the possibility of the accumulation of internal stresses that consistently stimulated the additional penetration of cobalt atoms. Obviously, this mechanism of substitution atoms displacement can be considered as a primarily athermal one. As shown earlier, the athermal mechanism of mass transfer of the substitutional and interstitial atoms was realized by the explosive kinetics of $\gamma-\alpha$ transformation in iron-nickel alloys [25, 26]. Since the athermal nature of the process of cobalt atoms penetration into the depth of alloy due to CMT, it cannot be considered as a diffusion process. It is reasonably being called an atomic transport process that does not require the thermal activation.

During the $\gamma \leftrightarrow \varepsilon$ transformations in the local regions of the alloy, the internal stresses of tension and compression emerged in accordance with the sign of the volume effect of direct $\gamma-\varepsilon$ (increase of specific volume) and reverse $\varepsilon-\gamma$ (decrease of specific volume) transformations. Stretched areas arose due to direct

Fig. 6. The depth of penetration ( $x$ ) of the Co isotope as a function of the quantity $(N)$ of $\gamma \leftrightarrow \varepsilon$ cycles without annealing (1) and with annealing at $250^{\circ} \mathrm{C}$ (2) and $325^{\circ} \mathrm{C}(3)$

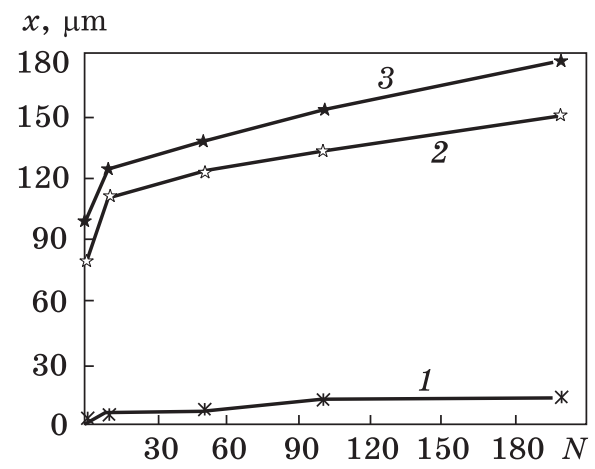


$\gamma-\varepsilon$ transformation at the low temperatures, when the relaxation processes were inhibited and internal stresses were preserved. This created the conditions for the Co atoms' displacement in such areas. Obviously, the reverse $\varepsilon-\gamma$ transformation created the conditions for the migration of substitutional atoms through the athermal mechanism by a lesser extent.

One of the possible mechanisms for mass transfer in the process of thermal cycling is the dislocation mechanism. As shown in Refs. [43, 44], the mobile dislocations can perform the role of mobile traps for point defects, viz. for interstitial atoms, and to facilitate their transport by increasing the effective diffusion coefficient. The effectiveness of such transfer increases in the conditions of significant stresses that cause the movement of acentric dislocations. But with the increase in the total density of dislocations, the proportion of fixed dislocations increases, which leads to the inhibition of mobile dislocations, thereby slowing down the mass transfer. Significant contribution of such dislocation mechanism for the transfer of atoms is pronounced especially at low temperatures, when the thermally activated redistribution of atoms by the mechanism of random wandering is ineffective due to the small amplitude of atomic oscillations and due to the small frequency of atomic jumps.

Another possible mechanism for mass transfer in the process of thermal cycling is the interstitial (or crowdion) mechanism, which consists in the displacement of interstitial atoms along the close-packed planes $(111)_{\gamma}$ and $(001)_{\varepsilon}$ in the crystalline lattices of f.c.c. austenite and h.c.p. martensite, respectively. As known, the crowdions play an important role in the diffusion processes and the displacement of radiation defects $[40,41]$. Interstitial atoms should also play a significant role in cases of high internal stresses, e.g., at high-rate deformation, which occurs at MT. They can occur in the places of high local stresses generated at the edges of martensitic crystals. The penetration of Co atoms into the depth of the sample from thin surface layer due to the CMT (interstitial stream) can be considered as a macroscopic manifestation of the interstitial mechanism of mass transfer. The transfer of Co atoms to the macroscopic depth, taking into account the known property of crowdions to the aggregation, allows supposing the formation of clusters containing several crowdions (crowdion complexes). This may contribute to the reduction of the energy of their formation and determines the possibility of transferring a larger number of atoms through this mechanism. In this case, the crowdions manifest the property to move in the field of stresses occurring in the crystal with structural deformation, particularly with the MT [41]. It was concluded that, in the process of the motion of crowdion complexes at a speed exceeding the velocity of sound in a crystal, they appear to be sufficiently stable configurations and decay into separate crowdions only at temperatures 

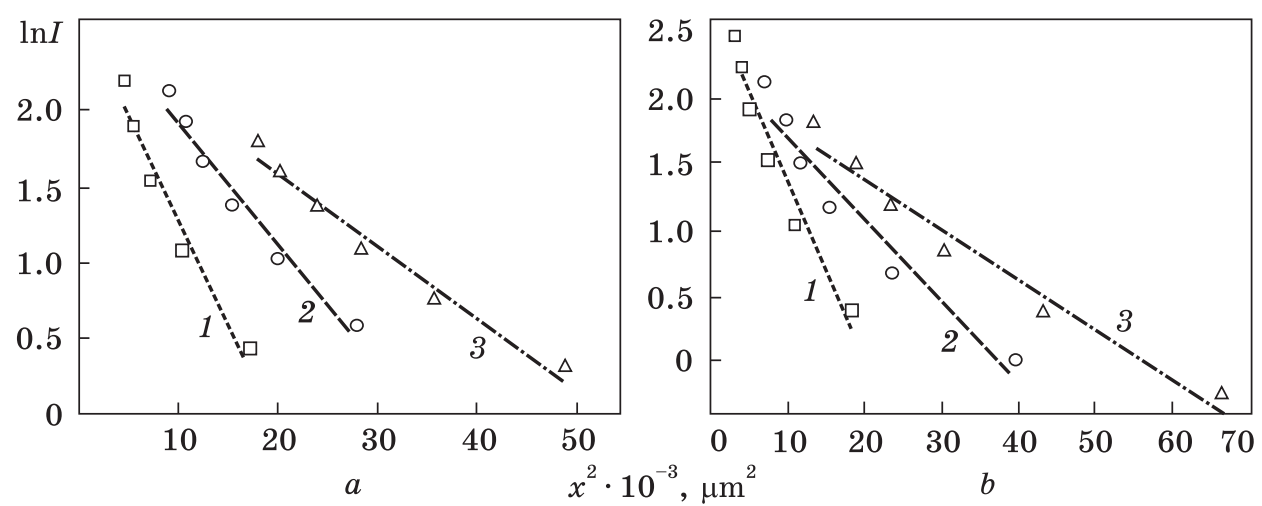

Fig. 7. Calculated dependences of $\ln I\left(x^{2}\right)$ after one (1), 100 (2), and 200 (3) $\gamma \leftrightarrow \varepsilon$ cycles and subsequent diffusion annealing at $250^{\circ} \mathrm{C}(a)$ and $325^{\circ} \mathrm{C}(b)$. Fitting by linear curves is also performed

closed to the melting temperature. This important circumstance explains the transfer of a significant number of Co atoms in our experiments on its penetration into the depth of sample as a result of the CMT. Authors of Ref. [41] admitted the possibility of high-rate processes of the crowdion transfer and its complexes at MT, which did not require the thermal activation.

In order to detect the thermally activated component of atomic transport processes (diffusion) in the phase-hardened $\Gamma 18 \mathrm{C} 2$ alloy, the influence of isothermal annealing on the parameters of cobalt diffusion were further studied. After thermal cycling of samples with different number of $\gamma \leftrightarrow \varepsilon$ transformations, they were additionally maintained for 2500 hours at the temperatures of 250 and $325^{\circ} \mathrm{C}$, thereby implementing the diffusion annealing, which further stimulated the diffusion of cobalt atoms into the depth of samples. The annealing temperature was chosen in such way that it does not exceed the temperature of the end of reverse $\varepsilon^{-\gamma}$ transformation to prevent the occurrence of relaxation processes in the phase-hardened alloy. Under this annealing regime in the structure of the phase-hardened alloy, the accumulated chaotic stacking faults were stored. As a result, the possibility to determine the contribution of the CSF to the intensification of diffusion processes rose. Annealing at higher temperatures eliminates the influence of the CSF on diffusion processes in reverted austenite. After thermal cycling and additional isothermal annealings, the amount of $\varepsilon$-phase was over $90 \%$. This indicated the diffusion characteristics in the phase-hardened alloy were mainly related to the martensitic $\varepsilon$-phase.

To calculate the coefficients of cobalt diffusion, a linear range of the $\ln I=f\left(x^{2}\right)$ dependence obtained for diffusion annealing temperatures of $250{ }^{\circ} \mathrm{C}$ and $325^{\circ} \mathrm{C}$ was used (Fig. 7). Note that $\ln I=f\left(x^{2}\right)$ de- 
pendence was linear only in a certain approximation. As one can see in Fig. 7, there is a deviation of the experimental points from the linear dependence, which increased with the increase of the number of $\gamma \leftrightarrow \varepsilon$ cycles, that is, with the growth of the degree of phase hardening. The specified deviations from the linearity have a certain physical sense.

As known, the bulk diffusion character via the mechanism of random walks is characterized by a linear dependence in the $\ln I=f\left(x^{2}\right)$ coordinates. Diffusion profiles reconstructed in such coordinates deviate from the linear dependence. As a result of the approximation of graphs by the function $C=A \exp \left(-b x^{n}\right)$, the power indices $n$ (given in Table below) were obtained.

The deviation of the power index from $n=2$ to a value close to 1 indicates the prevailing contribution of another atoms transfer mechanism, characterized by the presence of additional driving force [42]. The role of such a force in this case play defects of the crystalline structure: dislocations, small-angle sub-boundaries of fragments and CSF, accumulated in the results of the CMT. It is demonstrable that at $T=250{ }^{\circ} \mathrm{C}, n$ does not increase with increasing the number of transformations. This indicates that the contribution of thermoactivated processes in the transfer decreases with the increasing the number of cycles. At $T=325{ }^{\circ} \mathrm{C}$, the $n$ value increased as a result of the increase in the contribution of bulk diffusion to the total diffusion flow.

Calculations showed that after the first cycle of transformations, the diffusion coefficient $D=2.9 \cdot 10^{-13} \mathrm{~cm}^{2} / \mathrm{s}$ at $325^{\circ} \mathrm{C}$. An increase in the number of $\gamma \leftrightarrow \varepsilon$ cycles results to a monotonic growth of $D$ to a value of $9.3 \cdot 10^{-13} \mathrm{~cm}^{2} / \mathrm{s}$ that means an increase of it due to the phase hardening not less than in four orders of magnitude as compared with the coefficient of self-diffusion. As a result of 500 transformation cycles, the coefficient increased by approximately 3.2 times in comparison to the first cycle. This value corresponded to the coefficient of stationary diffusion at $900{ }^{\circ} \mathrm{C}$. After 200 cycles, the growth rate of $D$ was reduced (Fig. 8).

A noticeable difference in the penetration depth (Fig. 6) and, consequently, $D$ (Fig. 8) at $250^{\circ} \mathrm{C}$ and $325^{\circ} \mathrm{C}$ was sufficient to calculate the activation energy $E$ of the Co diffusion. As revealed, the magnitude of

Index of power $(n)$ in approximation function $C=A \exp \left(-b x^{n}\right)$ for different diffusion annealing temperatures and number of martensitic $\gamma-\varepsilon$ transformations

\begin{tabular}{|c|c|c|c|}
\hline Number of $\gamma-\varepsilon$ transformations & 1 & 50 & 500 \\
\hline$T=250^{\circ} \mathrm{C}$ & 1.39 & 1.16 & 1.15 \\
$T=325^{\circ} \mathrm{C}$ & 0.99 & 1.01 & 1.30 \\
\hline
\end{tabular}



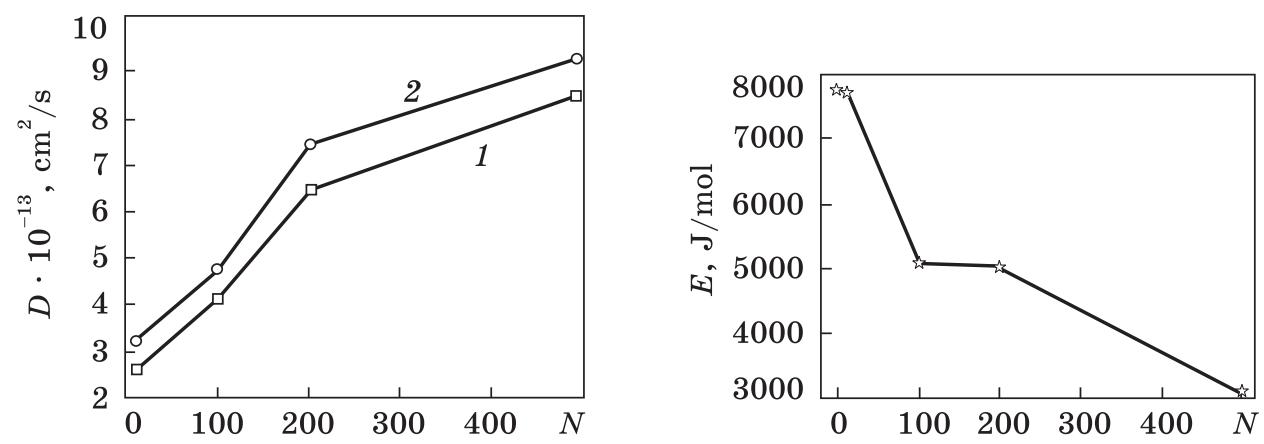

Fig. 8. Diffusion coefficient of Co vs. the number of $\gamma-\varepsilon-\gamma$ cycles after diffusive annealing at $250{ }^{\circ} \mathrm{C}(1)$ and $325^{\circ} \mathrm{C}(2)$

Fig. 9. Activation energy of Co diffusion depending on the $\gamma \leftrightarrow \varepsilon$ cycles' number

$E$ monotonically decreased with increasing the number of $\gamma \leftrightarrow \varepsilon$ cycles (Fig. 9). After 500 cycles, the $E$ value decreased by 2.6 times. The main change in the $E$ value (by 1.54 times) occurred at an increase in the number of cycles to one hundred.

The mechanism of thermally activated diffusion is associated with its acceleration in the region of crystal structure defects generated by direct $\gamma-\varepsilon$ and reverse $\varepsilon-\gamma$ transformations. Because of the annealing, following the cyclic transformations, the diffusion mobility of the substitutional atoms was additionally increased due to the effect of onedimensional and two-dimensional defects of the crystalline structure of residual austenite and $\varepsilon$-martensite formed during these transformations (dislocations, small-angle sub-boundaries of fragments, CSF). The maximum increase of the Co diffusion coefficient was observed with an increase in the number of thermal cycles to about one hundred, when the major increase in the density of defects in the crystalline structure in the f.c.c. and h.c.p. structures was fixed.

The contribution of various defects to the intensification of diffusion in the process of diffusion annealing was shown at various intervals of $\gamma-\varepsilon-\gamma$ cycling. An analysis of the regularities of the accumulation of structure defects of a different type as a result of cyclic $\gamma-\varepsilon-\gamma$ transformations allowed to determine a certain sequence of their influences on the Co diffusion (analogous to the influence on the diffusion of $\mathrm{C}$ atoms $[29,45])$ as follow:

(i) the effect of dislocations generated by $\gamma-\varepsilon-\gamma$ transformation was observed after the first cycle;

(ii) the increase in the contribution of the CSF occurred in the process of first $30-40$ cycles;

(iii) the disoriented small-angle sub-boundaries did not significantly affect the diffusion as a result of first 5-7 cycles, but subsequently 
continuously accumulated and effectively influenced on the diffusion processes already throughout the whole range of thermal cycling.

The main mechanism of the intensification of Co diffusion through the thermally activated mechanism is the acceleration of diffusion in the dislocation region. We have to take into account that small-angle sub-boundaries can be considered as polygonal dislocation walls. The influence of the CSF on the diffusion characteristics also indirectly relates to the effect of the dislocations, since the CSF can be represented as a complex of two partial dislocations with a stacking fault layer between them.

As a result of the annealing of phase-hardened samples at temperatures higher than $350{ }^{\circ} \mathrm{C}$, i.e. at the end of the reverse $\varepsilon-\gamma$ transformation, the CSF were no longer involved in accelerating of the diffusion processes, since they were practically completely annealed during this transformation.

\section{Conclusions}

Because of the $\gamma \leftrightarrow \varepsilon$ CMT in the $\Gamma 18 \mathrm{C} 2$ alloy, the CSF as well as subboundaries of austenite fragments and $\varepsilon$-martensite with increasing disorientation of crystal lattices were accumulated. As shown, the CMT can result to the formation of only small-angle sub-boundaries of the austenite fragments. However, the CMT cannot result to the formation of the new grains of reverted austenite differing from the orientation of the initial grain due to the accumulation of disorientation of the lattice, as it took place for iron-nickel alloys in a result of multiple $\gamma \leftrightarrow \alpha$ transformations. The CSF also showed the ability to be accumulated with increasing the number of $\gamma \leftrightarrow \varepsilon$ transformations. Concentration of the CSF increased with the heating of the quenched alloy in the interval of the reverse $\varepsilon-\gamma$ transformation at a rate higher than the critical one.

The heating to temperatures above $300{ }^{\circ} \mathrm{C}$ results to a significant decrease in the concentration of CSF. The interval of decrease of the CSF concentration coincides with the interval of reverse $\varepsilon-\gamma$ transformation. At the completion of the reverse transformation, the CSF completely disappeared.

The defect system of the crystalline structure, formed in the process of cyclic $\gamma \leftrightarrow \varepsilon$ transformations, and the degree of thermal stability of various defect types, determine the regularities of the intensification of diffusion processes in the phase-hardened alloy.

The depth of the Co atoms penetration in the phase-hardened $\mathrm{\Gamma} 18 \mathrm{C} 2$ alloy increases as the accumulation of internal stresses and defects in the crystalline structure (dislocations, fragments with small-angle subboundaries, CSF) during the $\gamma \leftrightarrow \varepsilon$-transformation processes. The transformation cycles provided cobalt penetration to the depth of $12 \mu \mathrm{m}$. The 
subsequent annealing of the phase-hardened alloy at $325^{\circ} \mathrm{C}$ provided a macroscopic depth of $170 \mu \mathrm{m}$. Significant increase in the mobility of substitution atoms via the $\gamma \leftrightarrow \varepsilon$ transformations on the example of the ${ }^{60} \mathrm{Co}$ isotope occur due to the action of two independent mechanisms: the athermal one and the mechanism of thermal activation.

The first mechanism was realized because of the diffusionless shifting character of direct $\gamma-\varepsilon$ and reverse $\varepsilon^{-\gamma}$ transformations (without diffusion annealing) due to the action of sign-changing stresses in the process of structural reconstruction of the crystal lattice.

The second possible mechanism for the transfer of Co atoms in the process of thermal cycling is the interstitial (crowdion) mechanism consisting in the displacement of interstitial atoms and their complexes along close-packed planes (111) and (001) $)_{\varepsilon}$ in crystalline lattices of f.c.c. austenite and h.c.p. martensite, respectively. Interstitial atoms can play a significant role in atomic transport processes in cases of high internal stresses, e.g., at a high-rate deformation, which takes place at MT. They can emerge in places of high local stresses generated at the martensitic crystal edges.

The mechanism of thermal activation was realized in the process of the subsequent diffusion annealing of the phase-hardened alloy due to acceleration of the diffusion in the region of accumulated defects of the crystal structure. The maximum increase of the diffusion coefficient of cobalt and the decrease of the diffusion activation energy occur at the increasing the number of thermal cycles to circa one hundred when the major increase in the density of the defects of the crystalline structure in f.c.c. austenite and h.c.p. martensite takes place.

After the first cycle of transformations, the diffusion coefficient $D$ for Co atoms was equal to $2.9 \cdot 10^{-13} \mathrm{~cm}^{2} / \mathrm{s}$ at $325^{\circ} \mathrm{C}$. When the number of $\gamma \leftrightarrow \varepsilon$ cycles increased, the depth of penetration of cobalt atoms increased by two times and $D$ grew monotonically up to $9.3 \cdot 10^{-13} \mathrm{~cm}^{2} / \mathrm{s}$, which meant its increasing (due to the phase hardening) at least up to four orders of magnitude as compared with stationary diffusion at the same temperatures. This value corresponded to the coefficient of stationary diffusion at $900{ }^{\circ} \mathrm{C}$. At the same time, the activation energy of diffusion of the cobalt atoms was monotonically reduced by 2.6 times.

There is a deviation of the concentration profiles over the depth of penetration of the cobalt atoms from the linear dependence in the coordinates of $\ln I=f\left(x^{2}\right)$, which is characteristic for the bulk character of diffusion through the mechanism of random walks. This allowed concluding that the contribution of bulk diffusion to the total diffusion flow increases as the temperature of diffusion annealing increases.

The revealed regularities of intensification of diffusion processes via the $\gamma \leftrightarrow \varepsilon$ transformations can be used in the simulation of the atomic mechanism of low-temperature diffusion (below $0.5 T_{\text {melt }}$ ), when the 
diffusion occurs mainly in the areas of the crystal-structure imperfections, i.e. defects.

The formation of a system of the crystal-structure defects in the metastable alloys by means of the CMT and the resulting significant increase of the diffusion mobility of substitutional atoms at low temperatures opens up new additional prospects for application of the chemical-and-thermal treatment methods. For instance, through the preliminary phase hardening, the surface metallization temperature of metastable Fe-based alloys can be reduced by several hundred degrees.

\section{REFERENCES}

1. S. Schumacher, R. Birringer, R. Strauss, and H. Gleiter, Acta Met., 37: 2485 (1989). https://doi.org/10.1016/0001-6160(89)90046-1

2. B.S. Bokshtein, Diffuziya v Metallakh [Diffusion in Metals] (Moscow: Metallurgiya: 1978) (in Russian).

3. W. Lan, S. Zhao, and W. Zhon. Mater. Express, 8, No. 3: 245 (2018). https:// doi.org/10.1166/mex.2018.1434

4. G.Ya. Bazeluk, V.I. Bondar, and Ie.N. Dzevin, Solid State Phenom., 130: 267 (2007). https://doi.org/10.4028/www.scientific.net/SSP.130.267

5. A. Aletdinov, S. Mironov, G.F. Korznikova, T. Konkova, R.G. Zaripova, M.M. Myshlyaev, and S.L. Semiatin, Metall. and Mat. Trans. A, 50, No. 3: 1346 (2019). https:// doi.org/10.1007/s11661-018-5070-9

6. P. He, X. Yue, and J.H. Zhang, Mater. Sci. Eng. A, 486, Nos. 1-2: 171 (2008). https://doi.org/10.1016/j.msea.2007.08.076

7. V.A. Andryushchenko, O.V. Bavol, T.L. Blinokhvatov, A.G. Garan, and E.M. Dzevin, Metallofiz. Noveishie Tekhnol., 32, No. 7: 883 (2010) (in Russian).

8. V.A. Andrushchenko and E.N. Dzevin, Materials Structure, 6, No. 2: 122 (1999).

9. V.A. Andryushchenko, O.V. Bavol, T.L. Blinokhvatov, A.G. Garan, and E.M. Dzevin, Metallofiz. Noveishie Tekhnol., 31, No. 9: 1257 (2009) (in Russian).

10. V.A. Kim and M.S. Kochetkov, Uprochnyayushchie Tekhnologii i Pokrytiya, No. 7 (127): 13 (2015).

11. V.V. Kovalenko, Eh.V. Kozlov, Yu.F. Ivanov, and V.E. Gromov, Fizicheskaya Priroda Formirovaniya i Evolyutsiya Gradientnykh Strukturno-Fazovykh Sostoyaniy $v$ Stalyakh $i$ Splavakh [The Physical Nature of the Formation and Evolution of Graded Structure-Phase States in Steels and Alloys] (Novokuznetsk: Poligrafist: 2009) (in Russian).

12. V.E. Gromov, Yu.F. Ivanov, E.G. Belov, V.B. Kosterev, and D.A. Kosinov, Usp. Fiz. Met., 17, No. 4: 303 (2016) (in Russian). https://doi.org/10.15407/ufm. 17.04.303

13. V.V. Kovalenko, Izvestiya VUZov. Chernaya Metallurgiya, 9: 25 (2004) (in Russian).

14. E.M. Dzevin, Nanoscale Res. Lett., 10: 117 (2015). https://doi.org/10.1186/ s11671-015-0785-7

15. K.A. Malyshev, V.V. Sagaradze, I.P. Sorokin, N.D. Zemtsova, V.A. Teplov, and A.I. Uvarov, Fazovyy Naklep Austenitnykh Splavov na Zhelezonikelevoy Osnove [Phase Hardening of Iron-Nickel-Based Austenite Alloys] (Moscow: Nauka: 1982) (in Russian).

16. V.V. Sagaradze,V.E. Danilchenko, Ph. L'Heritier, and V.A. Shabashov, Mater. Sci. Eng. A, 337, Nos. 1-2: 146 (2002). https://doi.org/10.1016/S0921-5093 (02)00023-0 
17. V.V. Savin,Yu.F. Ternovoy, V.A. Borkovskikh, A.V. Nedolya, and S.A. Sabanov, J. Magn. Magn. Mater., 157-158: 49 (1996). https://doi.org/10.1016/03048853(96)00006-6

18. A.V. Nedolya and V.Yu. Olshanetskyy, Novi Materialy i Tekhnologii v Metalurgii ta Mashynobuduvanni, 2: 29 (2013) (in Ukrainian).

19. V.E. Danilchenko, V.F. Mazanko, and V.E. Iakovlev, Nanoscale Res. Lett., 9: 322 (2014). https://doi.org/10.1186/1556-276X-9-322

20. A.V. Nedolya and D.Y. Shapar, Materialwiss. Werkstofftech., 47, Nos. 2-3: 128 (2016). https://doi.org/10.1002/mawe.201600481

21. A.V. Nedolya, Springer Proc.Phys., 183: 231 (2016). https://doi.org/10.1007/9783-319-30737-4_20

22. V.B. Brik, Diffuziya i Fazovyye Prevrashcheniya v Metallakh i Splavakh [Diffusion and Phase Transformations in Metals and Alloys] (Kiev: Naukova Dumka: 1985) (in Russian).

23. V.Yu. Danilchenko, V.F. Mazanko, and V.Ie. Yakovlev, Metallofiz. Noveish. Tekhnol., 31, No. 12: 1621 (2009) (in Ukrainian).

24. D.S. Gertsriken, M.E. Gurevich, Yu.N. Koval, V.M. Tyshkevich, and V.M. Falchenko, Termotsiklicheskaya Obrabotka Metallicheskikh Izdeliy [Thermocyclic Treatment of Metal Fabrics] (Leningrad: Nauka: 1982) (in Russian).

25. V.M. Mironov, T.F. Mironova, Yu.N. Koval, D.S. Gertsriken, and V.V. Alekseeva, Vestnik SamGU - Estestvennonauchnaya Seriya, No. 3 (43): 134 (2006) (in Russian).

26. Yu.N. Koval, D.S. Gertsriken, and V.P. Bevz, Metallofiz. Noveishie Tekhnol., 10: 32 (2010) (in Russian).

27. L.I. Lysak and B.I. Nikolin, Fizicheskie Osnovy Termicheskoy Obrabotki Stali [Physical Basis of the Heat Treatment of Steel] (Kiev: Tekhnika: 1975) (in Russian).

28. V.B. Brik, A.M. Kumok, B.I. Nikolin, and V.M. Falchenko, Metally, 4: 131 (1981) (in Russian).

29. V.I. Bondar, V.E. Danilchenko, A.V. Filatov, V.F. Mazanko, and V.E. Iakovlev, Usp. Fiz. Met., 19: 70 (2018). https://doi.org/10.15407/ufm.19.01.070

30. L.N. Larikov and V.M. Falchenko, Diffuziya $v$ Metallakh $i$ Splavakh (Ed. M.A. Krishtal) (Tula: TLI: 1968), p. 333 (in Russian).

31. M.S. Paterson, J. Appl. Phys., 23: 805 (1952). https://doi. org/10.1063/1.1702312

32. Ya. D. Vishnyakov, Defekty Upakovki v Kristallicheskoy Strukture [Stacking Faults in the Crystal Structure] (Moscow: Metallurgiya: 1970) (in Russian).

33. B. E. Warren, Progress in Metal Physics, 8: 147 (1959). https://doi.org/ 10.1016/0502-8205(59)90015-2

34.J.W. Christian, Acta Cryst., 7: 415 (1954). https://doi.org/10.1107/ S0365110X54001259

35. I.N. Bogachev and V.F. Egolaev, Struktura i Svoistva Zhelezomargantsevykh Splavov [Structure and Properties of the Iron-Manganese Alloys] (Moscow: Metallurgiya: 1973) (in Russian).

36. L.I. Lysak and I.B. Goncharenko, Fiz. Met. Metalloved., 31: 1004 (1971) (in Russian).

37. Yu.A. Polikarpov, P.L. Gruzin, and M.A. Shumilov, Zavodskaya Laboratoriya, 4: 417 (1955) (in Russian).

38. V. Danilchenko, E. Dzevin, and V. Sagaradze, J. Mater. Sci. Technol., 29, No. 3: 279 (2013). https://doi.org/10.1016/j.jmst.2012.12.016 
39. I.N. Bogachev, V.F. Egolaev, L.D. Chumakova, and R.M. Shklyar, Izvestiya VUZov. Chernaya Metallurgiya, 10: 140 (1967) (in Russian).

40. V.L. Indenbom, JETP Letters, 12, No. 11: 369 (1970).

41. A.V. Markidonov, M.D. Starostenkov, T.I. Neverova, and A.A. Barchuk, Lett. Mater., 1, No. 2: 102 (2011) (in Russian). https://doi.org/10.22226/2410-35352011-2-102-106

42. V.F. Mazanko, S.P. Vorona, and A.V. Filatov, Metallofizika, 17, No. 9: 74 (1995) (in Russian).

43. A. Filatov, A. Pogorelov, D. Kropachev, and O. Dmitrichenko, Defect and Diffusion Forum, 363: 173 (2015). https://doi.org/10.4028/www.scientific.net/ DDF.363.173

44. D.A. Kropachyov, A.E. Pogorelov, and A.V. Filatov, Metallofiz. Noveishie Tekhnol., 35, No. 6: 793 (2013) (in Russian).

45. V.E. Danilchenko, A.V. Filatov, V.F. Mazanko, and V.E. Iakovlev, Nanoscale Res. Lett., 12: 194 (2017). https://doi.org/10.1186/s11671-017-1978-z

Received April 4, 2019;

in final version, May 5, 2019

В.Ю. Данільченко, В.Ф. Мазанко,

О.В. Філатов, В.Є. Яковлев

Інститут металофізики ім. Г. В. Курдюмова НАН України, бульв. Академіка Вернадського, 36, 03142 Київ, Україна

ВПЛИВ ЦИКЛІЧНИХ МАРТЕНСИТНИХ $\gamma$-є-ПЕРЕТВОРЕНЬ НА ДИФУЗІЙНІ ХАРАКТЕРИСТИКИ КОБАЛЬТУ

В ЗАЛІЗОМАНГАНОВОМУ СТОПІ

В оглядовій статті аналізуються результати експериментальних досліджень впливу циклічних мартенситних перетворень (МП), - прямих $\gamma-\varepsilon$ (ГЦК-ГЩП) і зворотніх $\varepsilon-\gamma$ (ГЩП-ГЦК), - на дифузійні характеристики атомів Со у залізомангановому стопі Г18C2 (Fe-18,3 ваг.\% $\mathrm{Mn}-2,1$ ваг.\% $\mathrm{Si}$ ) з низькою енергією дефектів пакування (ДП). 3 використанням радіоактивних ізотопів методом авторадіографії та пошарового аналізу показано, що істотна інтенсифікація рухливости атомів Со $\gamma \leftrightarrow \varepsilon$-перетвореннями визначається двома різними незалежними механізмами: власне МП за рахунок дії циклічних знакозмінних внутрішніх напружень (атермічний механізм) і механізмом термічно активованої дифузії в області дефектів кристалічної будови, що сформувалися в процесі $\gamma-\varepsilon$ - і $\varepsilon-\gamma$ перетворень. Проаналізовано можливість транспорту атомів Со атермічним механізмом у процесі циклічних мартенситних перетворень (ЦМП) за рахунок переміщення міжвузлових атомів та їх комплексів вздовж щільнопакованих площин $(111)_{\gamma}$ і (001) $)_{\varepsilon}$ у кристалічних гратницях ГЦК-аустеніту та ГЩП-мартенситу відповідно (краудіонний механізм). При цьому враховувалася властивість краудіонних комплексів рухатися зі швидкістю, що перевищуе швидкість звуку в кристалі, в полі високих внутрішніх напружень, які виникають при високошвидкісній деформації аустеніту в процесі МП. Рентгенівськими методами на монокристалічних і полікристалічних зразках показано можливість накопичення в процесі ЦМП таких дефектів кристалічної будови як дезорієнтація кристалічної гратниці фрагментів і хаотичних дефектів пакування (ХДП). Інтенсифікація дифузійних процесів у фазонаклепаному стопі за механізмом термічної активації пов'язується із підвищенням рухливости атомів Со в області накопи- 
чених дефектів кристалічної будови. Аналіз закономірностей накопичення дефектів будови різного типу при підвищенні ступеня фазового наклепу уможливив визначення певної послідовности їхнього впливу на дифузійну рухливість атомів Со. Результати дослідження істотно розширюють фізичні уявлення стосовно дифузії атомів заміщення в стопах з розвинутою системою дефектів кристалічної будови різного типу (дислокацій, малокутових субмеж фрагментів, висококутових меж зерен, меж деформаційних двійників, ХДП). Одержані нові експериментальні результати можуть бути використані для розроблення моделі дифузії в області лінійних і площинних дефектів за низьких температур (нижче половини точки топлення). Окреслено перспективу практичного використання закономірностей інтенсифікації дифузії для оптимізації режимів технологічних хіміко-термічних процесів. Істотне пришвидшення (за допомогою ЦМП) дифузії атомів заміщення за низьких температур відкриває нові додаткові можливості технології дисперсійного твердіння.

Ключові слова: мартенситне перетворення, дифузія, дефекти пакування, дислокація, фазовий наклеп, субмежі фрагментів.

В. Ю. Данильченко, В. Ф. Мазанко,

А. В. Филатов, В. Е. Яковлев

Институт металлофизики им. Г. В. Курдюмова НАН Украины, бульв. Академика Вернадского, 36, 03142 Киев, Украина

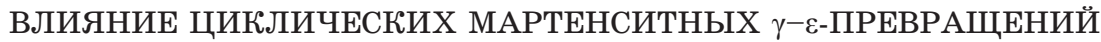 НА ДИФФУЗИОННЫЕ ХАРАКТЕРИСТИКИ КОБАЛЬТА В ЖКЕЛЕЗОМАРГАНЦЕВОМ СПЛАВЕ}

В обзорной статье анализируются результаты экспериментальных исследований влияния циклических мартенситных превращений (МП), - прямых $\gamma-\varepsilon$ (ГЦКГПУ) и обратных $\varepsilon-\gamma$ (ГПУ-ГЦК), - на диффузионные характеристики атомов Со в железомарганцевом сплаве $\Gamma 18 \mathrm{C} 2$ (Fe-18,3 вес.\% $\mathrm{Mn}-2,1$ вес.\% $\mathrm{Si})$ с низкой энергией дефектов упаковки (ДУ). С использованием радиоактивных изотопов методом авторадиографии и послойного анализа показано, что существенная интенсификация подвижности атомов Со $\gamma \leftrightarrow \varepsilon$-превращениями определяется двумя разными независимыми механизмами: собственно за счёт МП (атермический механизм) и механизмом термической активации в области дефектов строения, образованных в процессе $\gamma-\varepsilon-$ и $\varepsilon-\gamma$-превращений. Проанализирована возможность транспорта атомов Со атермическим механизмом в процессе циклических мартенситных превращений (ЦМП) за счёт перемещения междоузельных атомов и их комплексов вдоль плотноупакованных плоскостей (111) и (001) в в кристаллических решётках соответственно ГЦК-аустенита и ГПУ-мартенсита (краудионный механизм). При этом учитывалась способность краудионных комплексов двигаться со скоростью, которая превышает скорость звука в кристалле, в поле высоких внутренних напряжений, возникающих при высокоскоростной деформации аустенита в процессе МП. Рентгеновскими методами на моно- и поликристаллических образцах исследованы закономерности накопления в процессе ЦМП таких дефектов строения как дезориентация кристаллической решётки и хаотических дефектов упаковки (ХДУ). Интенсификация диффузионных процессов в фазонаклёпанном сплаве по механизму термической активации связывается с повышением подвижности атомов Со в области накопления дефектов кристаллического строения. Анализ закономерностей накопления дефектов стро- 
ения разного типа при повышении степени фазового наклёпа позволил установить определённую последовательность их влияния на диффузионную подвижность атомов Со. Результаты исследования развивают физические представления о диффузии атомов замещения в сплавах с развитой системой дефектов кристаллического строения разного типа (дислокаций, малоугловых субграниц фрагментов, высокоугловых границ зёрен, границ деформационных двойников, ХДУ). Полученные новые экспериментальные данные могут быть использованы для разработки модели диффузии в области линейных и плоскостных дефектов строения в области низких температур (ниже половины точки плавления). Определена перспектива практического использования закономерностей интенсификации диффузии для оптимизации режимов химико-термической обработки и процессов дисперсионного твердения метастабильных сплавов. Существенное ускорение (при помощи ЦМП) диффузии атомов замещения при низких температурах открывает новые дополнительные возможности технологии дисперсионного затвердевания.

Ключевые слова: мартенситное превращение, диффузия, дефекты упаковки, дислокация, фазовый наклёп, субграницы фрагментов. 